\title{
Gambaran histologis folikel ovarium sapi aceh pascavitrifikasi menggunakan etilen glikol
}

\author{
Arman Sayuti ${ }^{1}$, Jamilatun Hidayah ${ }^{2}$, Muslim $\mathrm{Akmal}^{3}$, Budianto Panjaitan ${ }^{1, *}$ \\ ${ }^{1}$ Laboratorium Klinik Fakultas Kedokteran Hewan Universitas Syiah Kuala, Banda Aceh \\ ${ }^{2}$ Program Studi Pendidikan Dokter Hewan Fakultas Kedokteran Hewan Universitas Syiah Kuala, Banda Aceh \\ ${ }^{3}$ Laboratorium Biologi, Embriologi, dan Histologi Fakultas Kedokteran Hewan Universitas Syiah Kuala, Banda Aceh
}

ABSTRAK: Penelitian ini bertujuan mengetahui gambaran histologis folikel ovarium sapi aceh pasca vitrifikasi menggunakan etilen glikol (EG) dengan berbagai konsentrasi berbeda yaitu 10\%, 20\% dan 30\%. Phosphate buffered saline (PBS), $0.25 \mathrm{M}$ sukrosa, 0.5 M sukrosa dan krioprotektan EG digunakan sebagai larutan vitrifikasi. Ovarium dipaparkan dengan larutan mengandung krioprotektan EG konsentrasi 10\%, 20\%, dan 30\% selama 5 menit masing-masing pada suhu kamar, dikemas dalam straw, lalu divitrifikasi dalam nitrogen cair $\left(-196{ }^{\circ} \mathrm{C}\right)$, dan thawing dalam air pada $37{ }^{\circ} \mathrm{C}$. Kondisi normal dan keutuhan folikel pascavitrifikasi diamati secara histologi. Hasil pengamatan menunjukkan bahwa ovarium setelah vitrifikasi dengan EG $10 \%$ dan $20 \%$ memperlihatkan presentase keutuhan folikel $32.83 \%$ dan $45.04 \%$, sedangkan EG 30\% memperlihatkan presentase tertinggi yaitu 54.96\%. Dari hasil penelitian ini dapat disimpulkan bahwa EG 30\% lebih baik dalam mempertahankan keutuhan folikel ovarium sapi aceh dibandingkan dengan EG $10 \%$ dan 20\%.

Kata kunci:

krioprotektan, ethylene glycol, kriopreservasi, vitrifikasi

\section{- PENDAHULUAN}

Sapi aceh merupakan salah satu jenis sapi potong lokal yang ada di Indonesia selain sapi bali dan sapi madura hasil persilangan antara sapi lokal (Bos sondaicus) dengan sapi turunan zebu dari India (Bos indicus) (Basri, 2006). Sapi potong lokal memiliki produktivitas dan efisiensi ekonomi yang maksimal pada kondisi yang terbatas sehingga lebih tepat dan ekonomis dikembangkan pada pola dan kondisi peternakan rakyat (Romjali et al, 2007). Salah satu upaya untuk menjaga populasi sapi aceh adalah melalui produksi embrio dengan teknologi fertilisasi in vitro (IVF). Teknologi IVF saat ini memanfaatkan ovarium segar, namun tidak dapat disimpan dalam waktu yang lama pada suhu kamar (Vieira et al. 2002). Keterbatasan waktu simpan ini dapat diatasi dengan teknik penyimpanan beku dengan metode vitrifikasi sehingga viabilitas folikel dapat dipertahankan.

Metode vitrifikasi menggunakan krioprotektan Etilen Glikol (EG). Etilen Glikol memiliki toksisitas yang lebih rendah dibanding DMSO, Propilen glikol, atau gliserol. Etilen glikol merupakan salah satu krioprotektan memiliki tingkat toksisitas paling rendah, daya permeasi cepat (Lucci et al. 2007). Mohamad (2005) menunjukkan bahwa ovarium mencit mampu tumbuh setelah vitrifikasi menggunakan krioprotektan EG 30\%. Sedangkan penggunaan konsentrasi EG $30 \%$ dan waktu pemaparan 5 menit cukup memadai untuk vitrifikasisel sel telur domba (Djuwita et al., 2000). Kemampuan EG dalam melindungi folikel saat vitrifikasi ovarium sapi aceh belum dilaporkan.

\section{- MATERI DAN METODE}

Koleksi Ovarium: Ovarium sapi aceh hasil koleksi dari RPH sesampai di laboratorium dibersihkan dari jaringan lain menggunakan gunting dan pinset. Ovarium ditempatkan dalam petri dish berisi larutan garam fisiologis $0,9 \%$ yang mengandung antibiotik penisilin $\mathrm{G} 100 \mathrm{IU} / \mathrm{ml}$.

Teknik Vitrifikasi Ovarium: Vitrifikasi ovarium dilakukan seperti metode vitrifikasi sel telur (Djuwita et al. 2000) dengan sedikit modifikasi. Ovarium dipaparkan secara berurutan dalam larutan PBS + sukrosa 0.25 M; PBS + sukrosa $0.5 \mathrm{M}$; PBS + sukrosa $0.5 \mathrm{M}+$ krioprotektan $10 \%$; dan PBS + sukrosa $0.5 \mathrm{M}+$ krioprotektan EG 10\%, 20\% dan $30 \%$ selama masing-masing 5 menit. Ovarium dikemas dalam straw, dipaparkan pada uap nitrogen cair selama 10 detik dan langsung dimasukkan kedalam nitrogen cair. Ovarium dibiarkan di dalam nitrogen cair minimal selama 30 menit lalu dilakukan penghangatan. Straw diambil dari nitrogen cair, dibiarkan di udara selama 10 detik lalu dimasukkan kedalam air dengan suhu $37{ }^{\circ} \mathrm{C}$ sampai mencair. Segera straw dipotong, jaringan ovarium dikeluarkan dan dimasukkan berturut-turut kedalam larutan PBS + sukrosa 0.5 M; PBS + sukrosa 0.25 M; dan PBS (3 kali) selama masing-masing 5 menit.

Diterima: 31-10-2018 | Direvisi: 29-12-2018 | Disetujui: 05-01-2019

(C) 2018 CC-BY-SA. Ini adalah artikel Open Access yang didistribusikan berdasarkan ketentuan dari Creative Commons Attribution ShareAlike 4.0 International License (https://creativecommons.org/licenses/by-sa/4.0/). 
Pemeriksaan Histologi: Jaringan ovarium didehidrasi dalam alkohol, dijernihkan dalam silol, dan ditanam dalam parafin. Jaringan disayat secara serial dengan ketebalan 5 $\mu \mathrm{m}$. Preparat dideparafinisasi, direhidrasi, dan diwarnai dengan hematoksilin-eosin (HE).

Analisis Data: Data sajikan secara deskriptif.

\section{- HASIL DAN PEMBAHASAN}

Hasil penelitian terhadap ovarium sapi aceh pascavitrifikasi dalam penelitian ini ditampilkan pada Tabel 1. Hasil menunjukkan bahwa konsentrasi EG 30\% memiliki presentase tertinggi dalam mempertahankan keutuhan ovarium sapi aceh, sedangkan presentase terendah pada konsentrasi EG 10\%. Konsentrasi EG 10\% dan EG 20\% banyak ditemukan folikel yang mengalami kerusakan.

Tabel 1 Presentase folikel utuh pascavitrifikasi

\begin{tabular}{|cc|}
\hline Kelompok Perlakuan & Folikel Utuh (\%) \\
\hline EG 10\% & 32.83 \\
EG 20\% & 45.04 \\
EG 30\% & 54.96 \\
\hline
\end{tabular}

Kerusakan folikel dapat disebabkan oleh beberapa faktor, yaitu: Pertama, konsentrasi krioprotektan yang digunakan tidak memadai untuk mencegah pembentukan kristal es intraseluler dan melindungi ovarium dari kerusakan selama proses pembekuan. Kristal es intraseluler secara mekanis dapat merusak organel sel, sehingga menyebabkan kematian sel (Gao \& Critser 2000). Kedua, waktu pemaparan yang kurang lama sehingga krioprotektan yang masuk (penetrasi) ke dalam jaringan ovarium tidak mencukupi. Ketiga, penggunaan kemasan straw meningkatkan volume larutan dan barier antara larutan dengan nitrogen cair sehingga mengurangi kecepatan penurunan suhu saat vitrifikasi dan kecepatan pencairan kembali saat warming. Kecepatan penurunan suhu dan pencairan kembali saat warming sangat mempengaruhi keberhasilan vitrifikasi (Vajta et al. 1998).

Hasil pemeriksaan histologis ovarium sapi aceh yang divitrifikasi dengan kriopotektan EG konsentrasi $10 \%$ dan $20 \%$ tampak mengalami kerusakan dan lisis pada sel-sel folikel (Gambar 1A,B) serta 30\% memiliki kualitas yang lebih baik (Gambar 1C,D). Morfologi ovarium setelah vitrifikasi mengalami kerusakan pada jaringan ovarium berupa pecahnya sel-sel folikel, piknotik inti sel korteks, robeknya sel-sel granulosa dan oosit. Kerusakan robeknya sel-sel granulosa yang mengelilingi sel telur. Hal ini menunjukkan bahwa vitrifikasi menggunakan EG $10 \%$ dan EG 20\% menurunkan kualitas ovarium sapi aceh. Hal tersebut mungkin dikarenakan konsentrasi krioprotektan yang digunakan tidak memadai untuk mencegah pembentukan kristal es intra seluler dan melindungi ovarium dari kerusakan selama proses pembekuan. Secara mikroskopis ovarium sapi aceh yang divitrifikasi menggunakan EG $30 \%$ dapat dilihat seperti: sel teka eksterna, sel teka interna, sel-sel granulosa, zona pelusida dan oosit masih dalam keadaan normal tidak mengalami lisis dan kematian pada sel-sel folikelnya.
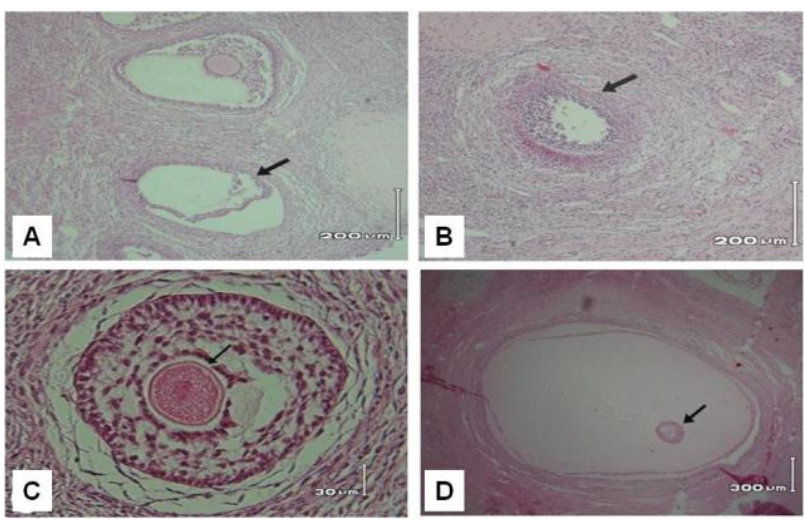

Gambar 1 Histologis folikel ovarium sapi aceh pasca vitrifikasi menggunakan EG 10\% (A), 20\% (B), dan 30\% (C-D). (A-B)

Folikel sekunder (tanda panah) mengalami kerusakan dan lisis pada sel-sel folikel, (C) Folikel sekunder, (D) Folikel tertier, (C-

D) Folikel dan sel telur terlihat normal (tanda panah).

\section{- SIMPULAN}

Bahan krioprotektan etilen glikol dalam media preservasi konsentrasi $30 \%$ yang sangat baik untuk kriopreservasi ovarium sapi aceh dengan metode vitrifikasi.

\section{- INFORMASI PENULIS}

Penulis untuk Korespondensi

*BP: budi@unsyiah.ac.id

Laboratorium Klinik Fakultas Kedokteran Hewan Universitas

Syiah Kuala, Banda Aceh

\section{- PUSTAKA ACUAN}

Basri H. 2006. Penelusuran Arah Pembibitan Sapi Aceh. Jurusan Peternakan Fakultas Pertanian Universitas Syiah Kuala Darussalam, Banda Aceh.

Djuwita I, Boediono A, Sukra Y. 2000. Morphology and fertilization rate of vitrified ovine oocytes matured in vitro. 14th International Congresson Animal Reproduction. Stockholm, July 2-6. Abst. 2:202.

Gao D, Critser JK. 2000. Mechanisms of cryoinjury in living cells. ILAR J, 41: 187-196.

Lucci CM, Schreier LL, Machado GM, Amorim CA, Bao SN, Dobrinsky JR. 2007. Effects of storing pig ovaries at 4 or $20 \mathrm{oC}$ for different periods of time on the morphology and viability of pre-antral follicles. Reprod Dom Anim, 42: 76-82.

Mohamad K, Djuwita I, Boediono A, Supriatna I. 2005. Vitrifikasi ovarium mencit menggunakan etilen glikol dan DMSO sebagai krioprotektan dan viabilitasnya pasca auto transplantasi di subkapsula ginjal. Media Kedokteran Hewan, 21:23-27.

Romjali E, Mariyono W, Hartati DB. 2007. Rakitan Teknologi Pembibitan Sapi Potong. Loka Penelitian Sapi Potong, Grati Pasuruan. Balai Pengkajian Teknologi Pertanian Jawa Timur.

Vajta G, Holm P, Kuwayama M, Booth PJ, Jacobsen H, Greve T, Callesen H. 1998. Open pulled straw (OPS) vitrification: a new way to reduce cryoinjuries of bovine ova and embryos. Mol Reprod Dev, 51: 53-58.

Vieira AD, Mezzalira A, Barbieri DP, Lehmkuhl RC, Rubin MIB, Vajta G. 2002. Calves born after open pulled straw vitrification of immature bovine oocytes. Cryobiology, 45:91-94. 